\title{
HAIR, FEET, BODY, AND CONNECTEDNESS IN "SONG OF MYSELF"
}

\author{
TAYLOR HAGOOD
}

'I reject nothing,' says Walt.

If that is so, one must be a pipe organ at both ends, so everything runs through.

-D. H. Lawrence ${ }^{1}$

A CENTRAL PARADOX in Walt Whitman's "Song of Myself" is its simultaneous championing of individuality and democracy. On one hand, Whitman positions the individual as the predominant vehicle and measuring stick of perception, judgment, and value. At the same time, he promotes fluidity, boundlessness, and connectedness characterized by ideals of democratic social equality. Scholars have long identified this paradox, but its resolution has been elusive: reconciling Whitman's extreme focus on the individual to his equally intense focus on the many requires some difficult imaginative machinations. ${ }^{2}$ Yet negotiating this problem is central to the poem's political, social, sexual, racial, and linguistic aspects.

One key to understanding Whitman's complicated presentation of "individuality versus democracy" lies in his depiction and positioning of body in "Song of Myself." Particularly important is his alignment of the human body along horizontal and vertical axes. Whitman portrays the head and the feet as the body's extreme connection points. These points (head and feet) may be the boundaries of a fluid and consolidated entity, or they may represent extremes that serve not to solidify but rather to fragment and disconnect the body and the self. Connectedness and consolidation embody Whitman's democratic ideal and are attainable only when the head and feet successfully make contact with each other and with the earth. This connectedness occurs most obviously in a horizontal orientation of the body, a position that Whitman associates with death and birth, the connection points of the entrance into and the exit out of life. Whitman characterizes the "middle" of the body and of life in the form of the nondemocratic and more individually significant vertical orientation. Connectedness may be achieved in vertical orientation when the remote contact point, the head, connects with the direct contact point, the feet, by means - oddly enough — of hair, which may reach from head to foot. 
Whitman uses images of "feet" and "hair" throughout the poem to reconcile the individual-democratic/vertical-horizontal ideals. Connectedness results from a consolidated line of connection both vertically and horizontally. When this connection is inconstant or broken, the individual becomes isolated from the many, and the ideals of simultaneous individuality and democracy - which must exist together in Whitman's figuration - fail to be realized. Whitman drives his point home at the poem's conclusion by positioning himself as the horizontally-oriented point of contact with which the reader must gain connectedness, metaphorically letting his or her hair down by the "extending" process of reading the poem. In the earth of the poem as well as the literal earth, Whitman awaits the reader's arrival and the historical, political, sexual, and social democratizing that accompanies that arrival.

The first step in understanding Whitman's paradox is understanding his dividing and fragmenting of self. Mark Maslan has accurately identified the importance of division in the poem. Maslan discusses scholars who posit "division" as a problem in Whitman's work because they see division as standing at odds with Whitman's democratic effort and unity. These critics attempt to resolve the problem, but Maslan notes that they fail to understand and apply the fact that "division is a vital principle of Whitman's poetics." Maslan then opens an important door in considering the function of division in Whitman's poetical rhetoric:

Rethinking division in this manner-as enabling rather than debilitating - would involve re-examining a whole series of relationships in Whitman in which critics have seen union as the organizing principle: the relationship between body and soul, body and text, form and content, man and man, people and government. And, of course, it would involve reassessing Whitman's view of Union itself. This task remains for future studies. $^{3}$

Whitman depicts identity as divided, with $I$ standing in opposition to myself. This split appears in the very first line, "I celebrate myself." Whitman fills in the division between the objectified $I$ and the objectified myself with the action of celebration, and, in later versions of the poem, of singing. This depiction of the self anticipates twentieth-century writers who theorize self, especially the crisis of split-identity, such as Jacques Lacan and Jean-Paul Sartre..$^{5}$ Mark Bauerlein discusses Whitman's split of self in terms of Lacan's "mirror stage," extending the division of self and othered self to include "the role language plays in frustrating (as opposed to facilitating) self-expression":

That is, along with the problem of overcoming inherited styles to express a distinctively American self, and the problem of allowing a repressed unconscious identity to emerge in a way that exceeds euphoric by short-lived catharsis, Whitman also faces the dilemma of wielding an intractable, objectifying form-language-to represent a vigorous, transient person-a subject. ${ }^{6}$ 
Bauerlein explains that the "obvious way to obviate the alienating separation between a subject and the words it uses to manifest itself is to assert a mystical connection between the two," and so "when, in his prose disquisitions, Whitman ascribes an occult bond between self and word, he assigns to language spiritual qualities rather than bringing the self down to rhetorical or empirical levels" (135). This "occult bond" between the self and the word constitutes a rich and ambiguous middle ground of connectedness in which the subject and language intermix.

Although, as Bauerlein argues, "Whitman's body ... [is] a selfreflexive text whose meaning and value precede linguistic formulation, ... a corporeal identity in disregard of linguistic difference [that] affords auto-tellic, auto-erotic self-expression" (141), a split identity nevertheless becomes an empirical problem when Whitman transfers the dynamics of the psychological and linguistic split between $I$ and myself to the material parallel of the body. ${ }^{7}$ This figuration presents a consolidated entity existing between the two extremes feet and head, with body as the middle space. These contact points are important, because feet are the contact point with earth, with the real, and as humans are positioned vertically the head becomes the farthest extreme from contact with the earth. Whitman's rhetoric establishes a Nietzschean opposition between the Apollonian connection point, the head, and the Dionysian connection point, the feet. ${ }^{8}$ The Dionysian parallel establishes the connection between democracy, horizontalness, and earth. Although positioned vertically across the earth, everyone is equal when spread horizontally, and the American democratic ideal that Whitman promotes in his preface to the first edition Leaves of Grass emerges.

Complete connectedness and democractic equality in "Song of Myself" occur when the connection points of head and feet are equally connected with earth, a position more easily obtainable and more often characterized by horizontal rather than vertical orientation. In horizontal orientation, contact points expand from two to infinity. Fluidity and boundlessness become the rule, and a horizontal center or middle develops. ${ }^{9}$ Particularly highlighting this "middleness" is the line "But I do not talk of the beginning or the end" ( $L G 30$ ). The horizontal center unifies, and this unification is exemplified in the following lines: "And that all the men ever born are also my brothers, and the women my sisters and lovers, / And that a kelson of the creation is love" (LG 33). In light of the very horizontal image of love's being a "kelson" or spine of creation, the ultimate horizontalness of democracy and the democratic spirit appear in this passage. Contact points exist all along the spine of existence.

Images of centeredness and horizontality particularly appear in Section 6 of the poem. Here, Whitman establishes the importance of horizontalness, middleness, and connectedness with several images. The primary material of boundlessness and democracy and horizontalness is 
grass. "Sprouting alike in broad zones and narrow zones," grass ignores race, class, and tribe, " $[\mathrm{g}]$ rowing among black folks as among white, / Kanuck, Tuckahoe, Congressman, Cuff, I give them the same, I receive them the same." Social equality emerges by means of the horizontal deployment of grass.

At the same time that the horizontal orientation of grass carries democratic significance, its vertical positioning also offers connectedness and consolidation. In the following lines, Whitman equates grass with hair and hair with offspring proceeding from the ultimate horizontal equalizer and one life-connection point: death. As Kuniko Yoshizuki notes, Whitman uses grass "as a motif of life-death-rebirth," an idea also suggested by the geological model of the earth's strata of dead horizontal matter bringing forth vertical elements of life-from blades of grass to human beings - that themselves die and come to rest in a new layer of horizontal strata to begin the process all over again. ${ }^{10}$ This use of grass is evidenced in the following lines:

And now it seems to me the beautiful uncut hair of graves.

Tenderly will I use you curling grass,

It may be you transpire from the breasts of young men,

It may be if I had known them I would have loved them;

It may be you are from old people and from women, and from offspring taken soon out of their mothers' laps,

And here you are the mothers' laps.

I wish I could translate the hints about the dead young men and women,

And the hints about old men and mothers, and the offspring taken soon out of their laps.

What do you think has become of the young and old men?

And what do you think has become of the women and children?

They are alive and well somewhere,

The smallest sprout shows there is really no death,

And if ever there was it led forward life, and does not wait at the end to arrest it,

And ceas'd the moment life appear'd.

All goes onward and outward, and nothing collapses,

And to die is different from what any one supposed, and luckier. (LG 34-35)

In this passage Whitman presents a symbiotic relationship between vertical and horizontal orientation. Grass, vertically oriented, represents the individual while - since it is horizontally spread - also representing the many. Death, the ultimate and irrevocable horizontal positioning, thus becomes a producer, a signifier of Dionysian vitality. The figure of 
hair is significant because, as a continuous, non-split strand, it connects with earth, thus connecting the remote extremity to earth, signifying full connection. Furthermore, in this passage, gender equality obtains as both males and females "give birth" to grass. As democracy moves "onward and outward," its strength grows so that none of the framework "collapses." In the circular nature of progression from death to rebirth implied in Whitman's construction and championing of the horizontal, Whitman prefigures the modernist conception of circular time and the theme of death and rebirth derived from Frazer's The Golden Bough. ${ }^{11}$ Death and birth thus become not merely negative and positive, respectively, but also part of a process in which horizontalness can be extended.

This imagery of hair and horizontality continues in Section 11 of the poem, informing birth, the opposite life-connection point from death. In this section, twenty-eight male bathers occupy a horizontal position as they lie on their backs in the water. In this case, the bodies of the young men floating on their backs are utterly connected with fluidity by association with the medium of water. The young men are completely connected, and as with the grass emanating from the laps of the dead, so the young men become as women with their swollen pregnant bellies capable of giving birth. Stressing the connectedness of the young men, water runs "from their long hair, / Little streams pass'd all over their bodies" and presumably back to the body of water from whence the streams came. Whitman extends the democratizing and equalizing effect of cross-gendering the bathers by having the twenty-ninth bather be a woman. In this case, the sexual connectedness clearly emerges alongside the social.

Bodily horizontality and the connection points, feet and hair, occur in an equally conspicuous manner in Section 5. In this scene, the poet loafs in a horizontal position on the grass, a "middle" position in which no one part of the body monopolizes the point of contact of self with the myriad earth. Stressing the democratic equality of the image, Whitman writes that "I believe in you my soul, the other I am must not abase itself to you, / And you must not be abased to the other." "I mind how once we lay such a transparent summer morning," Whitman writes, "How you settled your head athwart my hips and gently turn'd over upon me, / And parted the shirt from my bosom-bone, and plunged your tongue to my bare-stript heart, / And reach'd till you felt my beard, and reach'd till you held my feet." Reaching from one extremity to the other along the lines of horizontalness signifies complete encompassing of the body, and thus complete connectedness.

Read in terms of vertical orientation, this scene carries a different type of connectedness and negotiation of life and death. A metaphorical vertical interpretation of the passage posits the foot as a phallic image 
and the beard as pubic hair. In this case, the connection points find themselves reversed, with hair characterizing the connecting point of the vertically-oriented member to the body. In such imagery, the vertically-oriented entity becomes the connection point, and the "death" produced from such contact might potentially produce life. Thus, Whitman's argument that "the kelson of creation is love" finds its vertical fulfillment.

Connectedness and consolidation in vertical orientation, however, sometimes prove difficult to attain in "Song of Myself." By its very nature, vertical orientation signifies lack of full connectedness in that it positions one extremity as unconnected and lacking a center from which self may emanate and spread and forgo boundaries and fulfill the carnivalesque commingling that characterizes Whitman's "celebration" of the democratic ideal. Mikhail Bakhtin describes the carnivalesque in Rabelais and His World, designating, in strikingly Whitmanesque terms, lower body strata and upper body strata of society and finding their metaphorical counterparts on the human body. These two extremes interact fluidly in carnival, or the moment and space of boundlessness in which "all forms of popular-festive merriment and grotesque realism thrust down, turn over, push headfirst, transfer top to bottom, and bottom to top, both in the literal sense of space, and in the metaphorical meaning of the image." 12 Whitman's depiction of the body falls in the camp of grotesque realism rather than classical idealism, with his relentless stress on carnivalesque corporeality full of barbaric yawps and belched words. This body is the one that can level the two strata and provide a fluid equilibrium and interconnection between them. The problem of reorienting the human from a vertical to horizontal position or at least modifying verticality thus becomes a central mission in the poem. The democratic fluidity and centeredness finds itself replaced by isolated individuality.

An example of vertical orientation isolating the individual from democracy and equality appears in Section 10 in the form of a runaway slave. In this politically and racially charged instance, even the feet cannot connect to the earth. A runaway slave who is "limpsy and weak" appears in the speaker's kitchen. The slave has "bruis'd feet," the metaphorical suggestion of impotence further showing vertical orientation as impaired. ${ }^{13}$ When the speaker heals the slave's bruised contact points, strengthening his mobility and the possibility of his escape to freedom, the democratic ideal may be realized. This literal connectedness emerges when the speaker has the slave "sit next me at [the] table." At the same time, the metaphorical healing of the slave's bruised phallus reconfirms his sexual connectedness and introduces the possibility of life in a context of stifled social death.

Whereas hair metaphorically completes connectedness in Section 6 , in another vignette in Section 10 hair becomes the literal vehicle of 
connectedness in vertical orientation by its potential for reaching from head to foot and to earth. In this scene, a Native-American bride has "coarse straight locks descend[ing] upon her voluptuous limbs and reach [ing] to her feet." In this case, the bride's opposite extremity from the contact point of earth, of horizontalness, actually reaches to that contact point, her feet. In Whitman's ideology (and in American ideology, generally), the native girl herself contains a perpetual horizontalness that remains undisturbed by verticalness, symbolized by the length of her hair. And with her connectedness, she and the trapper, whose connectedness appears in his horizontally-oriented lounging and "his luxuriant beard and curls protect[ing] his neck," represent fluid horizontalness and democratization when they join in a union characterized by racial ambiguity (particularly on the trapper's part) and intermixture. Again, horizontalness finds itself modified to achieve connectedness and consolidation.

In Section 9, a different sort of horizontalizing occurs. In this case, dead grass lies horizontally in stacks, and Whitman stretches "atop of the load." He then proceeds to "roll head over heels, and tangle [his] hair full of wisps" ( $L G$ 36-37). In this fluid inversion of contact points, equalizing and horizontalizing occur, enhancing Whitman's middleness as being completely fluid and boundless. While the red girl and trapper's marriage creates an equalizing situation and the runaway slave's healing represents installment into equality, rolling head over heels modifies the vertical orientation, connecting contact points and opening the potentialities of democratization.

The significance of these images lies in their connecting life and death and connecting them with individuality and democracy. In a poem informed by a historical context of sectional conflict that would ultimately result in civil war, the concept of death creating the exuberance and possibility of life seems a concept not so terribly inaccessible. Eventually, the concern about connecting self to the many would constitute a postbellum crisis of national identity that would inform the local color and regional writing in which individual pockets of the nation would be explored and presented in literature to bolster the unification of the national body.

In light of the importance of feet and hair, the final lines of the poem take on a particularly significant corporeal meaning:

I depart as air, I shake my white locks at the runaway sun, I effuse my flesh in eddies, and drift it in lacy jags.

I bequeath myself to the dirt to grow from the grass I love, If you want me again look for me under your boot-soles. 
You will hardly know who I am or what I mean,

But I shall be good health to you nevertheless,

And filter and fibre your blood.

Failing to fetch me at first keep encouraged,

Missing me one place search another,

I stop somewhere waiting for you. ( $L G 89$ )

In these final lines, the split, bounded human body of Whitman diffuses into the boundless existence of spirituality, into the air, by shaking his "white locks," an image that informs the manifold images of Whitman as "one of the roughs," with his long hair and defiance of bounds. ${ }^{14}$ Indeed, Whitman's very description of himself in one of his reviews of his own work presents him as:

of American breed, of reckless health, his body perfect, free from taint from top to toe . . . beard short and well mottled with white, hair like hay after it has been mowed in the field and lies tossed and streaked . . . a face that absorbs the sunshine and meets savage or gentleman on equal terms - a face of one who eats and drinks and is a brawny lover and embracer - a face of undying friendship and indulgence toward men and women, and of one who finds the same returned many fold . . . a spirit that mixes cheerfully with the world. ${ }^{15}$

At the same time that this new fluid entity dissolves into air it commits itself into the horizontalized earth and awaits the contact of feet. Again, the Apollonian contact point has been reversed with the Dionysian contact point. And, as the earth produces the uncut hair of graves, so Whitman nourishes his readers who stand vertically over his horizontalness.

In one sense, these lines refer to the body and to the literal earth, but they also include literary significance-they inform the act of reading "Song of Myself." By means of the solitary, individualistic act of reading the "leaves" of the book upon which the poem is written, Whitman offers access to the many, to democratization, to horizontalness. ${ }^{16}$ Ultimately, horizontalness perhaps remains unattainable in such an Apollonian and individualistic activity as reading, but the poem's sweeping, horizontally-arranged lines and struggle for common, visceral language characterize an effort to create and perpetuate a peculiar unification of the individual and the many in an America constantly moving "onward and outward." 17

The University of Mississippi 


\section{NOTES}

1 D. H. Lawrence, Studies in Classic American Literature (1923; rpt. New York: Viking, 1961), 165.

2 For a detailed description of these scholars and their works, see Mark Maslan's "Whitman and His Doubles: Division and Union in Leaves of Grass and Its Critics," American Literary History 6 (Spring 1994), 119-139.

3 Maslan, 136.

4 Whitman, Leaves of Grass: Comprehensive Reader's Edition, ed. Harold W. Blodgett and Sculley Bradley (New York: New York University Press, 1965), 28. Abbreviated $L G$. The motif of bodily horizontality and verticality remains a central component of the text throughout the revisions of the poem.

5 Jacques Lacan, "The Mirror Stage as Formative of the Function of the I as Revealed in Psychoanalytical Experience," Écrits: A Selection, trans. Alan Sheridan (New York: Norton, 1977), 1-7. Jean-Paul Sartre, Being and Nothingness: An Essay in Phenomenological Ontology, trans. By Hazel E. Barnes (Secaucus, NJ: Citadel Press, 1974).

6 Bauerlein, "Whitman's Language of the Self," American Imago: Studies in Psychoanalysis and Culture 44 (Summer 1987), 134-135.

7 Discussions of Whitman's use of body include: Harold Aspiz, Walt Whitman and the Body Beautiful (Urbana: University of Illinois Press, 1980); M. Jimmie Killingsworth, Whitman's Poetry of the Body: Sexuality, Politics, and the Text (Chapel Hill: University of North Carolina Press, 1989); Michael Moon, Disseminating Whitman: Revision and Corporeality in Leaves of Grass (Cambridge, Mass.: Harvard University Press, 1991); and Tenney Nathanson, Whitman's Presence: Body, Voice, and Writing in Leaves of Grass (New York: New York University Press, 1992).

8 Friedrich Nietzsche, The Birth of Tragedy and The Case of Wagner, trans. Walter Kaufmann (New York: Vintage, 1967). For an examination of the similarities in thought between Whitman and Nietzsche, see C. N. Stavrou, Whitman and Nietzsche: A Comparative Study of Their Thought, University of North Carolina Studies in the Germanic Languages and Literatures, no. 48 (Chapel Hill: University of North Carolina Press, 1964).

9 Here, I mean "fluidity" in the sense that one can transcend the bounds of oneself in the sense that Mikhail Bakhtin identifies in Rabelais and His World, trans. Helen Iswolsky (Bloomington: Indiana University Press, 1984). Michael Moon discusses fluidity in Whitman's texts in terms of seminal flow, citing medical treatises warning against masturbation during the nineteenth century.

10 Yoshizaki, "The Theme of Death in Leaves of Grass," Kyushi American Literature 22 (May 1981), 43. See Joseph Beaver's Walt Whitman-Poet of Science (New York: King's Crown, 1951) and Gay Wilson Allen's The New Walt Whitman Handbook (New York: New York University Press, 1975) for Whitman's interest in and knowledge of geology.

11 James George Frazer, The Golden Bough (New York: Macmillan, 1940).

12 Bakhtin, 370.

13 The shackles of slavery that bruise the slave's feet and cause the "galls" on his ankles metaphorically attempt to render the African American male impotent by exerting control over the sexual threat he poses. The suggestion of Whitman's restoring the slave's sexual freedom thus represents an especially significant implication of li- 
censed horizontality and connectedness by means of freedom and health for procreation. For discussion of Whitman's treatment of African-Americans see Leadie M. Clark, Walt Whitman's Concept of the American Common Man (New York: Philosophical Library, 1955); Ed Folsom, "Lucifer and Ethiopia: Whitman, Race, and Poetics before the Civil War and After," A Historical Guide to Walt Whitman, ed. David Reynolds (New York: Oxford University Press, 2000), 45-95; Martin Klammer, Whitman, Slavery, and the Emergence of Leaves of Grass (University Park: Pennsylvania State University Press, 1995); and Luke Mancusco, The Strange Sad War Revolving: Walt Whitman, Reconstruction, and the Emergence of Black Citizenship, 1865-1876 (Columbia: Camden House, 1997).

14 Whitman was one of the most photographed people of his time. Although he did not yet of course have "white locks" in the 1855 edition of the poem, the frontispiece engraving of him portrayed a disheveled, longer-haired, bearded poet violating the bounds of nineteenth-century taste as even the limits of his body in the image-specifically his lower legs and feet-finally fade away. See Folsom's "Whitman and Photographs of the Self” in Walt Whitman's Native Representations (New York: Cambridge University Press, 1994), 127-188, for discussion of the significance of photographs of Whitman.

\section{Quoted in Aspiz, Walt Whitman and the Body Beautiful, 5.}

16 Robert F. Fleissner argues that Whitman acquired the concept of pages of poetry as "leaves" of grass from Wordsworth's essay, "The Tables Turned: An Evening Scene on the Same Subject," a work in which William Carlos Williams sees the similar idea of the "common ground [(earth, common people, etc.) being] itself a poetic source," highlighting the fluid democratic context of Whitman's construction of the poem ("Ironic Fertility: 'Defoliating' the Title Leaves of Grass," Thalia: Studies in Literary Humor 15 [1995], 77-79). Leaves of Grass represents Whitman's attempt to produce a thoroughly organic volume; its title highlights the fact that the physical object of the book replicates nature when its leaves emanate from the spine in the same way leaves of grass sprout horizontally from the vertical earth. Folsom notes that Whitman was conscious of poetry as sprouting from the compost of language-a strikingly vertical/ horizontal configuration-in "Whitman and Dictionaries," Walt Whitman's Native Representations, 12-26.

17 C. Carroll Hollis's citing of Jakobson's horizontal/vertical axis of metaphor and metonymy in Language and Style in Leaves of Grass (Baton Rouge: Louisiana State University Press, 1983) suggests how Whitman's revolutionary long sweeping lines with their relentless horizontality balance the inherent vertical $/$ metaphorical nature of poetry. 